\title{
SOSIALISASI KEBIJAKAN KEBIJAKAN MEA BAGI PELAKU INDUSTRI KECIL DAN MENENGAH DI KABUPATEN BANDUNG BARAT
}

\author{
Putri Trulline, Evie Ariadne Shinta Dewi, dan Benazir Bona Pratamawaty \\ Universitas Padjadjaran \\ E-mail: putri.trulline@unpad.ac.id
}

\begin{abstract}
ABSTRAK. Pemerintah daerah harus ikut menyiapkan diri dalam menghadapi MEA, karena sebagai kebijakan internasional yang lahir dari sebuah bentuk perjanjian internasional, keberadaan MEA akan berdampak bagi kehidupan masyarakat negara anggota perjanjian tersebut. Pemerintah KBB sudah selayaknya mengantisipasi dampak ini, salah satunya dengan mengeluarkan kebijakan yang berlandaskan pada kebijakan pemerintah pusat terkait MEA. Idealnya, segera setelah kebijakan dibuat, maka pemerintah daerah perlu menyosialisasikannya kepada seluruh stakeholders termasuk kepada masyarakat luas guna menyiapkan masyarakat dalam menghadapi fase baru kehidupan perekonomian negara Indonesia di tingkat kawasan.

Di sinilah letak pentingnya peran komunikasi politik dalam penetapan kebijakan baru. Dalam hal ini, merujuk pada kebijakan Pemerintah Provinsi Jawa Barat, maka pemerintah daerah KBB yang merupakan salah sau dari 27 kota kabupaten di Jawa Barat, perlu mengeluarkan kebijakan komunikasi politik tertentu dalam rangka menyosialisasikan pemberlakuan MEA guna menyiapkan seluruh stakeholders terutama masyarakat awam dalam menghadapi fase baru tatanan perekonomian bangsa saat ini. Hal ini sangat perlu dilakukan mengingat kebijakan internasional dalam tingkatan regional senantiasa berdampak langsung pada kehidupan sehari-hari masyarakat awam. Dengan adanya sosialisasi yang dilakukan oleh tim PPM Unpad bekerjasama dengan Disperindag terkait kebijakan kebijakan MEA bagi para pelaku industri kecil dan menengah di Kabupaten Bandung Barat diharapkan dapat membantu para UKM mempersiapkan kehadiaran MEA.
\end{abstract}

ABSTRACT. Local governments must participate in preparing themselves to face the AEC, because as an international policy that was born from a form of international treaties, the existence of the AEC will have an impact on the lives of the people of the treaty countries. The KBB government should properly anticipate this impact, one of which is by issuing policies based on central government policies related to the MEA. Ideally, as soon as the policy is made, the local government needs to socialize it to all stakeholders, including the general public, in order to prepare the community in facing a new phase of the economic life of the Indonesian state at the regional level. Herein lies the important role of political communication in setting new policies. In this case, referring to the policy of the Provincial Government of West Java, the KBB regional government, which is one of the 27 regency cities in West Java, needs to issue a specific political communication policy in order to socialize the implementation of the AEC to prepare all stakeholders, especially ordinary people, in facing a new phase. the current economic structure of the nation. This is very necessary considering that international policies at the regional level always have a direct impact on the daily lives of ordinary people. With the socialization carried out by the PPM Unpad team in collaboration with Disperindag related to the AEC policy policies for small and medium industry players in West Bandung Regency, it is expected to be able to help SMEs prepare for the AEC presence.

\section{PENDAHULUAN}

Pemerintah daerah selayaknya ikut menyiapkan diri dalam menghadapi MEA, karena sebagai kebijakan internasional yang lahir dari sebuah bentuk perjanjian internasional, keberadaan MEA akan berdampak bagi kehidupan masyarakat negara anggota perjanjian tersebut. Mereka yang akan terkena dampak tersebut tidak hanya para pelaku usaha besar, namun juga pelaku usaha kecil, termasuk daerah-daerah yang baru lahir sebagai kota atau kabupaten hasil pemekaran seperti Kabupaten Bandung Barat (KBB). Pemerintah KBB sudah selayaknya mengantisipasi dampak ini, salah satunya dengan mengeluarkan kebijakan yang berlandaskan pada kebijakan pemerintah pusat terkait MEA. Idealnya, segera setelah kebijakan dibuat, maka pemerintah daerah perlu menyosialisasikannya kepada seluruh stakeholders termasuk kepada masyarakat luas guna menyiapkan masyarakat dalam menghadapi fase baru kehidupan perekonomian negara Indonesia di tingkat kawasan.

Merujuk pada kebijakan Pemerintah Provinsi Jawa Barat tentang perlunya pemda melakukan sosialisasi MEA, maka pemerintah daerah KBB yang merupakan salah satu dari 27 kota kabupaten di Jawa Barat, perlu mengeluarkan kebijakan komunikasi politik tertentu dalam rangka menyosialisasikan pemberlakuan MEA guna menyiapkan seluruh stakeholders terutama masyarakat awam dalam menghadapi fase baru tatanan perekonomian bangsa saat ini. Hal ini sangat perlu dilakukan mengingat kebijakan internasional dalam tingkatan regional senantiasa berdampak langsung pada kehidupan sehari-hari masyarakat awam. Kehadiran MEA di tengah-tengah masyarakat harus diikuti dengan pemahaman dan perubahan cara berpikir masyarakat dalam menghadapi persaingan dunia usaha yang pada gilirannya menyentuh seluruh aspek kehidupan bermasyarakat.

Berdasarkan pengamatan awal peneliti terhadap kebijakan komunikasi politik pemda KBB, masih belum ada kebijakan khusus yang dibuat untuk menyosialisasikan kebijakan-kebijakan pemerintah terutama mengantisipasi tantangan MEA kepada masyarakat luas. Hal ini ditunjukkan dengan tidak adanya kegiatan atau kebijakan komunikasi politik yang dilakukan oleh Dinas Komunikasi dan Informasi KBB dalam mengkomunikasikan pemberlakuan MEA kepada masyarakat.

Berdasarkan jenisnya, sosialisasi dibagi menjadi dua: sosialisasi primer (dalam keluarga) dan sosialisasi sekunder (dalam masyarakat). Menurut Goffman kedua 
proses tersebut berlangsung dalam institusi total, yaitu tempat tinggal dan tempat bekerja. Dalam kedua institusi tersebut, terdapat sejumlah individu dalam situasi yang sama, terpisah dari masyarakat luas dalam jangka waktu kurun tertentu, bersama-sama menjalani hidup yang terkukung, dan diatur secara formal. Untuk itu kami mencoba untuk memberikan sosialisasi terkait apa saja hal-hal yang harus dipersiapkan oleh para pelaku industri kecil menengah dalam menghadapi MEA.

\section{METODE}

Pelaksanaan Sosialisasi tentang Kebijakan-kebijkan MEA bagi para pelaku industri kecil dan menengah di Kabupaten Bandung Barat dilakukan dengan memanfaatkan potensi sumber daya yang dimiliki oleh Disperindag Kab. Bandung Barat dengan hasil observasi kegiatan riset yang dilakukan disana. Kegiatan ini juga menjadi bagian langsung dari upaya implementasi Tri Dharma Perguruan Tinggi.

Dalam pelaksanaannya, kegiatan sosialisasi kebijakankebijakan MEA bagi para pelaku industri kecil dan menengah di Kab. Bandung Barat akan dilakukan dengan mempertimbangan berbagai aspek seperti materi lietrasi, khalayak yang dihadapi, masalah yang berkembang serta lingkungan yang mendukung.

Kegiatan ini akan dilaksanakan dengan menggunakan beberapa metode pendekatan sebagai berikut:

1) Ceramah dan tanya jawab; Metode ini digunakan untuk memberi wawasan kepada peserta tentang media sosial dan kegunaannya. Metode ini bersifat interaktif sehingga peserta difasilitasi juga untuk dapat mengemukakan pertanyaan-pertanyaan terkait dengan literasi media

2) Brainstorming dan Diskusi:Metode ini digunakanauntuk menghimpun pengalaman, pendapat atau keingintahuan peserta terkait dengan masalah media dan informasi. Melalui proses ini maka peserta difasilitasi untuk mengemukakan pandangannya atau memiliki sikap terhadap media dan penggunaannya.

3) Peragaan dan tindakan baik secara individu maupun kelompok: Metode ini digunakan untuk melatih masyarakat secara langsung dan juga untuk menghasikan kompetensi dalam melakukan literasi media dan informasi yang lebih positif dan fungsional.

Tentunya dalam pelaksanaan metode kegiatan PKM ini tidak terlepas dari peran serta aktif Disperindag Kab Bandung Barat dan para pelaku usaha industri kecil dan menengah yang ada di Kab Bandung Barat. Materi yang disampaikan merupakan materi yang mereka butuhkan guna mengembangkan usaha yang sedang mereka geluti, materi yang disampaikan meliputi topik standar perdagangan berbasis produk, HKI, PIRT dll.

\section{HASIL DAN PEMBAHASAN}

Hasil yang telah dicapai pada acara sosialisasi ini adalah sebagai berikut
Sebelum pelaksanaan PPM ini tim melakukan survey lokasi, kami dimudahkan dengan langsung bertemu Sekertaris Kepala Dinas Perindustrian dan Perdagangan, selanjutnya kami memeproleh data jumlah peserta unutk mengikuti pelatihan judul pelatihan yang kami buat ialah "Sosialisasi Kebijakan-Kebijakan MEA Bagi Pelaku Industri Kecil dan Menengah di Kabupaten Bandung Barat" Kami melakukan diskusi awal dan perijinan dengan kepala bidang argo industri. Selanjutnya kami melakukan koordinasi dengan tim terkait teknis pelaksanaan dan kebutuhan yang diperlukan saat pelatihan. Koordinasi baik dengan tim maupun Sekertaris Kepala Dinas terus kami lakukan sampai pada waktunya, bertempat di Ruang Rapat Dinas Perindustrian dan Perdagangan kami melaksanakan pelatihan.

Pada tahap awal pelaksanaan pelatihan para pelaku IKM diberikan pengetahuan tentang Hak Merek dan E-Commerce para pelaku IKM. Hak Merek adalah hak atas tanda yang berupa gambar, nama, kata, hurufhuruf, angka-angka, susunan warna, atau kombinasi dari unsur-unsur tersebut yang memiliki daya pembeda dan digunakan dalam kegiatan perdagangan barang dan jasa. diberikan pengetahuan tentang bagaimana mereka bisa memiliki HKI prosedur yang harus ditempur dan syaratsyarat yang harus dipersiapkan juga mereka diberikan pengetahuan bagaiamana memanfaatkan media digital unttuk memasarkan produknya agar bisa dikenal lebih luas oleh masyarakat.

Merujuk pada pemahaman diatas maka tim tertarik untuk memberikan pemahaman kepada para pelaku IKM mengenai Hak Merek dan manfaat menggunakan E- Commerce. Kami tertarik untuk mengajak para pelaku IKM agar dapat memasuki pasar ASEAN dengan melakukan eksport produk yang mereka buat dengan memanfaatkan E-Commerce.

Adapun hasil yang dicapai dari kegiatan Pengabdian Pada Masyarakat tentang Sosialisasi Kebijakan-Kebijakan MEA Bagi Pelaku Industri Kecil dan Menengah di Kabupaten Bandung Barat adalah terjadinya penambahan pengetahuan dan pemahaman tentang MEA, cara memiliki Hak Merek dan memanfaatkan E-Commerce dalam memasarkan produk yang mereka buat agar dapat menembus pasar ASEAN. Pengetahuan dan pemahaman ini dapat diukur dengan melihat praktik yang mereka lakukan selama pelatihan.

Tahap utama dalam kegiatan ini adalah pelatihan cara-cara dan syarat-syarat yang harus ditempuh guna memiliki Hak Merek bagi para pelaku IKM di KBB.

Evaluasi program dilakukan dengan memberikan pertanyaan-pertanyaan kepada peserta pelatihan, pertanyaan yang diajukan mencakup tiga aspek yaitu penilaian peserta akan materi dan program pelatihan, instruktur pelatihan, dan juga pemahaman dan manfaat yang dirasakan.

Selain itu juga tim PPM tentang Sosialisasi Kebijakan-Kebijakan MEA Bagi Pelaku Industri Kecil 
dan Menengah di Kabupaten Bandung Barat juga meminta tanggapannya peserta dari materi yang telah disampaikan oleh para pemateri, yaitu Dr Evie Ariadne Shinta Dewi, M.Pd, Dr Ferry Hadiantoo, M.M, Ria Anjani.

Peserta menilai bahwa materi dan program pelatihan sudah baik. Menurut peserta penyajian materi pelatihan sudah dibawakan dengan baik dan menarik. Mereka menilai bahwa apa yang disampaikan oleh pelatih dapat dimengerti dengan mudah.

Penilaian atas instruktur lebih bagus lagi. Peserta menganggap instruktur pelatihan memahami dan menguasai materi pelatihan, penyampaian materi dengan sistematika yang baik. Saat sesi Tanya jawab, instruktur dianggap dapat memahami pertanyaan dan menjawab dengan sangat baik serta dikaitkan dengan pengalaman peserta ajar. Sikap dan antusiasme instruktur pelatihan juga membuat peserta bersemangat untuk belajar, ditambah lagi dengan adanya doorprize yang diberikan membuat suasana pelatihan semakin hidup. Saat pelatihan, peserta tidak sedikitpun merasa jenuh karena instruktur selalu mengajak peserta untuk berinteraksi, selain itu waktu pelatihan juga sudah diracang agar tepat waktu.

\section{SIMPULAN}

Adapun keberlanjutan program pengabdian pada masyarakat ini adalah hal yang harus dilakukan di masa mendatang, berupa kerja sama untuk meneruskan pelatihan serupa, agar tercapai tujuan-tujuan sebagai berikut: Secara kuantitatif bertambahnya pelaku IKM di Kabupaten Bandung Barat yang paham akan Masyarakat Ekonomi Asean; Secara kualitatif meningkatnya pengetahuan dan pemahaman selain itu secara aplikatif dapat melakukan upaya-upaya untuk dapat menembus pasar ASEAN dengan memahami Hak Merek dan E-Commerce dalam memasarkan produk yang mereka buat.

\section{DAFTAR PUSTAKA}

Departemen Perdagangan RI. Buku Menuju ASEAN Economic Community 2015. Jakarta.

Goffman, Erving,. 1961. Asylums: Essay son the Social Institution of Mental Patients and Other Inmates. New York: Penguin Books. 